\title{
Diallel analysis of yield and quality traits of melon fruits
}

\author{
Anne Katherine de Araújo Barros ${ }^{1 *}$, Glauber Henrique de Sousa Nunes ${ }^{2}$, Manoel Abílio de Queiróz $^{3}$, Elaíne Welk Lopes Pereira ${ }^{2}$ and \\ José Hamilton da Costa Filho
}

Received 9 August 2010

Accepted 9 January 2011

\begin{abstract}
The purpose of this study was to estimate the general and specific combining ability of melon hybrids to identify the best combinations. Six parents and their respective hybrids were evaluated in a complete randomized block design with three replications. The following traits were assessed: total number of fruits, average fruit weight, yield, longitudinal diameter, transversal diameter, flesh thickness, internal cavity size, flesh firmness, and soluble solids. The traits total fruit number, yield, flesh firmness and soluble solids content are controlled by additive and non-additive effects, while average fruit weight, longitudinal diameter, flesh thickness, internal cavity size are controlled by additive effects. The most appropriate crosses for breeding of Cantaloupe, Honey dew, Piel del sapo, Meloa and Amarelo melon are, respectively: Gold Mine x Hy Mark, AF-646 x AF-1749, Meloa x Rochedo and AF-646x Rochedo.
\end{abstract}

Key words: Cucumis melo, combining ability, choice of parents, selection.

\section{INTRODUCTION}

Cantaloupe or muskmelon (Cucumis melo L.) is one of the main crops grown in northeastern Brazil. The states of Rio Grande do Norte and Ceará are the largest producers of this fruit and account together for more than $90 \%$ of the national production. The continuous implementation of new technologies has led to a constant expansion of the melon agribusiness in Brazil. Melon is an important sector of agribusiness in Brazil because it attracts foreign exchange and employment to the semi-arid Northeast, triggering regional development (Crisóstomo et al. 2008)

Melon is the most polymorphic species of the cucurbit family, which is particularly true for fruit-related traits (Luan et al. 2010). For the breeding of this vegetable, germplasm is available including from accessions collected on small farms to hybrids developed by seed companies, representing a source of numerous possible crosses to generate lines. In this context, one key aspect is the choice of parents for the breeding of improved lines, since the improvement process is long. Erroneously chosen parents would therefore result in no profit, but in a waste of time and resources.

Among the methodologies used to choose the parents and segregating populations, the diallel analysis deserves consideration. It uses information about the performance of parents and their hybrids. From the diallel crosses the general and SCA can be estimated. The general combining ability (GCA) is related to additive effects, representing the average parental performance in hybrid combinations,

\footnotetext{
${ }^{1}$ Syngenta Seeds Ltda, Rua Sousa Pinto, 93, 59.631-070, Mossoró, RN, Brazil. *E-mail: anne.barros@syngenta.com

${ }^{2}$ Universidade Federal Rural do Semi-Árido, s/n, 137, 59.625-900, Mossoró, RN, Brazil

${ }^{3}$ Universidade do Estado da Bahia, Av. Edgard Chastinet Guimarães, s/n, 48.905-680, Juazeiro, BA, Brazil
} 
while the specific ability (SCA) is related to non-additive effects, traitizing the deviations of hybrid combinations from the average parental performance. The GCA allows the identification of parents with higher frequency of favorable alleles, while the SCA indicates the most promising hybrid combinations (Ferreira et al. 2002, Valério et al. 2009). In addition, the diallel scheme helps analyze the nature and magnitude of gene effects that control traits of economic importance. Knowledge on the trait inheritance is useful to define the strategy of a breeding program (Feyzian et al. 2009).

In view of these considerations, the objectives of this study were to determine the general and specific combining abilities of the parents to identify the best hybrid combinations and study the gene effect on yield and quality-related traits of melon fruits.

\section{MATERIAL AND METHODS}

Hybrid seeds were produced in a vegetable garden of the plant science department of the Universidade Federal Rural do Semi-árido (UFERSA). The parents Meloa (Pele de sapo), AF-646, Rochedo, Gold Mine (Amarelo), AF1749 (Honey dew) and Hy Mark (Cantaloupe) were crossed in all possible combinations, without reciprocals, resulting in 15 hybrids.

The test with six parents and their hybrids was conducted in an experimental of the Fazenda Santa Júlia, in Mossoró, state of Rio Grande do Norte (lat $5^{\circ} 11^{\prime}$ S, long $37^{\circ} 21^{\prime} \mathrm{W} ; 18 \mathrm{~m}$ asl). The climate is BSwh (Köppen classification), that is very dry, with a rainy season in late summer/early autumn (Carmo Filho and Oliveira 1989).

The soil was tilled by moldboard plowing and disking, 14 days before planting. The seeds were sown in polystyrene trays with 128 cells, filled with commercial substrate. The transplant was done 14 days after planting in soil previously plowed and disked, the ridges were made with hoes and a drip-irrigation system installed. At transplanting, 12 tha $^{-1}$ of cattle manure was applied as base fertilization in the furrows. The mineral sources applied in irrigation water, in $\mathrm{kg} \mathrm{ha}^{-1}$, were $500 \mathrm{KCl}, 150$ urea, $550 \mathrm{CaNO}_{3}$, and $200 \mathrm{H}_{3} \mathrm{PO}_{4}$. Weeds were manually removed until 30 days after transplanting. The other cultural practices were according to the management recommendations for the crop in the state (Nunes et al. 2005).

The experiment was arranged in a randomized block design with three replications to evaluate 21 treatments (six parents and 15 hybrids). Each plot consisted of two
$5.0 \mathrm{~m}$ long rows with 10 plants. The spacing was $2.0 \mathrm{~m}$ between rows and $0.5 \mathrm{~m}$ between plants.

The fruits were evaluated for the traits: total number of fruits, average fruit weight, yield, soluble solids content, flesh firmness, flesh thickness, longitudinal diameter, transverse diameter and internal cavity size. To evaluate the fruit quality traits, 20 fruits per plot were randomly sampled, while for total fruit yield all fruits per plot were collected.

Diallel analysis was performed using the average data and the mean square analysis of variance, considering method II of model I, proposed by Griffing (1956). All tests were performed using software Genes (Cruz 2008).

\section{RESULTS AND DISCUSSION}

In agricultural experimentation it is imperative that treatments are evaluated as accurately as possible. The higher the experimental accuracy, the greater the likelihood of finding differences between the treatments. The coefficient of variation is the most commonly used indicator of the quality of experiments. Based on the classification Lima et al. (2004) for melon, the values can be considered average for all assessed traits. In this study, estimates of CV were within the range observed in other studies of evaluation of melon cultivars (Nunes et al. 2004, Nunes et al. 2005).

The estimates of GCA and SCA obtained in diallel analysis provide important information for breeding on the potential of parents for intra-population improvement and the utility for inter-population programs as well as use of lines for hybrids (Vianna 2000).

For the traits average fruit weight, longitudinal diameter, flesh thickness and internal cavity size a significant effect ( $p \leq 0.05$ ) was detected only for GCA (Table 1 ), indicating only additive effects in the control of these morphoagronomic characteristics. In this situation, methods of inter-population improvement can be used to increase the frequency of favorable alleles for these traits.

Several authors detected additive and non-additive effects in the genetic control of the trait average fruit weight (Lippert and Legg 1972, Kalb and Davis 1984a, Singh and Randhawa 1990, Monforte et al. 2004), contrasting with the results of this study. However, Feysian et al. (2009) observed a predominance of additive effects for average fruit weight in a diallel of local populations from Iran.

Paris et al. (2008) reported the presence of additive and non-additive effects for the trait longitudinal diameter, diverging from this study. Concerning flesh thickness, 
Table 1. Summary of the analysis of variance of the diallel system according to model 1, method II of Griffing (1956) and estimates of the square components of the general and specific combining ability of nine traits evaluated in six melon crosses and their hybrids

\begin{tabular}{|c|c|c|c|c|c|c|c|c|c|c|}
\hline \multirow[b]{2}{*}{ Sources of variation } & \multirow[b]{2}{*}{ df } & \multicolumn{9}{|c|}{ MS } \\
\hline & & $\mathbf{T N F}^{2}$ & $\begin{array}{c}\text { MFW } \\
\text { (g) }\end{array}$ & $\underset{\left(t h^{-1}\right)}{\text { YD }}$ & $\begin{array}{l}\text { TD } \\
\text { (cm) }\end{array}$ & $\begin{array}{c}\text { LD } \\
\text { (cm) }\end{array}$ & $\begin{array}{l}\text { FTh } \\
\text { (cm) }\end{array}$ & $\begin{array}{l}\text { ICS } \\
(\%)\end{array}$ & $\begin{array}{l}\text { FF } \\
(\mathbf{N})\end{array}$ & $\begin{array}{c}\text { SS } \\
(\%)\end{array}$ \\
\hline GCA & 5 & $853.36^{* *}$ & $161.02^{* *}$ & $486.82^{* *}$ & 0.54 & $9.08^{* *}$ & $0.11^{*}$ & $81.38^{* *}$ & $87.98^{* *}$ & $0.89^{*}$ \\
\hline SCA & 15 & $366.28^{* *}$ & 27.201 & $325.62^{* *}$ & 0.53 & 1.32 & 0.06 & 20.22 & $42.29^{*}$ & $0.93^{*}$ \\
\hline Error & 40 & 14.44 & 55.85 & 43.83 & 0.67 & 2.18 & 0.05 & 23.43 & 20.19 & 0.40 \\
\hline$\phi_{\mathrm{GCA}^{1}}$ & & 104.87 & 13.15 & 55.37 & 0.00 & 0.86 & 0.02 & 7.24 & 8.47 & 0.06 \\
\hline$\phi_{\mathrm{SCA}^{1}}$ & & 351.84 & 0.00 & 281.79 & 0.00 & 0.00 & 0.01 & 0.00 & 22.10 & 0.53 \\
\hline$\phi_{(\mathrm{GCA} / \mathrm{GCA}+\mathrm{SCA})}$ & & 0.23 & 1.00 & 0.16 & - & 1.00 & 0.67 & 1.00 & 0.28 & 0.10 \\
\hline
\end{tabular}

${ }^{1} \phi$ GCA and $\phi$ SCA: Square components of the general and specific combining ability. **, *: significant at $(\mathrm{P}<0.01)$ and $(\mathrm{P}<0.05)$ by the $\mathrm{F}$ test of Snedecor. ${ }^{2}$ Total number of fruits (TNF), mean fruit weight (MFW), yield (YD), transversal diameter (TD), longitudinal diameter (LD), flesh thickness (FTh), internal cavity size (ICS), flesh firmness (FF); total soluble solids (SS).

Kalb and Davis (1984a), Singh and Randhawa (1990) and Kitroongruang et al. (1992) observed significant effects for GCA and SCA and the presence of additive and nonadditive effects for internal cavity size. The same fact was mentioned by Paris et al. (2008) for flesh thickness.

Regarding the total number of fruit traits, yield, flesh firmness and soluble solids, significant effects were observed for GCA as well as for SCA $(\mathrm{p} \leq 0.05)$. The significance of GCA indicates the presence of additive effects, while significant SCA indicates non-additive effects (dominance and epistasis) in the genetic control of a trait (Ferreira et al. 2004). The traits for which both effects (additive and non-additive) were significant, the quadratic component of the SCA was predominant, since the ratio $\frac{\varphi_{G C A}}{\varphi_{G C A}+\varphi_{G C A}}$ was lower than 0.5 (Table 1). For these traits the exploitation of heterosis in melon breeding programs is certainly feasible.

Concerning total number of fruits, Singh and Randahawa (1990), Kitroongruang et al. (1992) and Zalapa et al. (2006) reported only the presence of additive effects, in contrast to the results of this study. Nevertheless, Monforte et al. (2004) found heterosis in some crosses, indicating the presence of non-additive effects in the genetic control, since heterosis depends on the dominance and square of the divergence (Bernardo 2002), and, in short, a direct function of the product of genetic distance by their respective dominance deviations (Hallauer and Miranda Filho 1988).

For fruit yield, Lippert and Legg (1972), Kalb and Davis (1984b) and Abadia et al. (1985) observed that yield is controlled by additive and non-additive effects, predominantly by the quadratic component of SCA.
However, Feysian et al. (2009) also observed additive and non-additive gene action, but with predominance of GCA. Paris et al. (2008) reported the presence of additive and non-additive effects for flesh firmness, confirming the results of this study.

With regard to the content of soluble solids, there is some controversy as to the genetic control. Some authors found a predominance of additive and non-additive effects (Cuarteiro et al. 1985, Kalb and Davis 1984a, Singh and Randhawa 1990), while others found no significant effect of SCA (Lippert and Legg 1972, Zalapa et al. 2006, Paris et al. 2008). Monforte et al. (2004) provided a good description of the contradictory results in melon for this trait in a study with Pele de Sapo melon. This author found non-additive effects in the crosses, suggesting that inheritance is specific to each cross.

A comparison of results from different articles showed that the estimates of GCA and SCA depend on the allele frequency and dominance level. It is therefore emphasized that the discrepant results between studies are mainly due to the group of parents used in the experiments. In addition, the environmental effect and analysis method also influence the estimates.

The GCA of a parent in the diallel is related to the frequency of favorable alleles for the trait expression. Accordingly, parents with higher or lower estimates contribute to obtain segregating populations with higher or lower means of the derived lines, respectively (Ferreira et al. 2004). It is noteworthy that when a higher mean is desirable for the trait, high and positive $\mathrm{g}_{\mathrm{i}}$ values indicate higher frequency of favorable alleles. However, when a lower trait mean would improve the genotype, high and negative values also indicate a higher frequency of favorable alleles. 
AKA Barros et al.

The parents Hy Mark and AF-646 with the highest GCA helped increase total number of fruits and yield. Meloa, AF-1749 and Rochedo as parents contributed to a reduction of these two traits. It was found that the parent Meloa contributed to increase the average fruit weight. The parent Hy Mark, in turn, with the lowest GCA, contributed to reduce the fruit size, as well as the parent AF-1749. A similar result was observed for longitudinal diameter. The parent Meloa increased flesh thickness, while AF-1749 reduced this trait. For the internal cavity size, the parents Rochedo, AF-646 and Hy Mark induced a reduction, while the others increased the trait values. Parents Rochedo, AF-1749 and Gold Mine contributed most to increase of flesh firmness, while Meloa, AF-646 and Hy Mark reduced the value of this trait. The soluble solids content was increased by the parents Hy Mark, and Rochedo and reduced by Meloa and AF-646 (Table 2). crosses Meloa x Rochedo, Meloa x AF-646 and Gold Mine x Hy Mark. The crosses Meloa x AF-1749 and Rochedo x Gold Mine stood out for flesh firmness, while the crosses AF-646 x Rochedo and Gold Mine x Hy Mark for soluble solids (Table 3).

The magnitude of specific combining ability (SCA) indicates the degree of complementation of the parents of a cross. A significant SCA indicates heterogeneous performance of the parents. In this case, it is not possible to predict the parental performance based only on the GCA because interactions occur between the parents due to the divergence in the dominant loci.

The melon is the cucurbit with greatest morphological polymorphism (Luan et al. 2010). There are several types or botanical varieties of melon. In Brazil, the most widely planted types belong to the variety inodorus. The most common types of this variety are amarelo, pele de sapo,

Table 2. Estimates of the effects of the general combining ability $\left(\mathrm{g}_{\mathrm{i}}\right)$ and mean (in brackets) of nine traits evaluated in melon crosses

\begin{tabular}{|c|c|c|c|c|c|c|c|c|c|}
\hline \multirow[b]{2}{*}{ Parents } & \multicolumn{9}{|c|}{$\mathbf{g}_{\mathbf{i}}$} \\
\hline & NFT $^{1}$ & $\begin{array}{c}\text { MFW } \\
\text { (g) }\end{array}$ & $\underset{\left(t \text { ha }^{-1}\right)}{Y D}$ & $\begin{array}{l}\text { TD } \\
\text { (cm) }\end{array}$ & $\begin{array}{l}\text { LD } \\
(\mathbf{c m})\end{array}$ & $\begin{array}{l}\text { FTh } \\
\text { (cm) }\end{array}$ & $\begin{array}{l}\text { ICS } \\
(\%)\end{array}$ & $\begin{array}{l}\text { FF } \\
(\mathrm{N})\end{array}$ & $\begin{array}{l}\text { SS } \\
(\%)\end{array}$ \\
\hline \multirow{2}{*}{ Meloa } & -6.21 & 141.63 & -3.34 & 0.22 & 1.07 & 0.08 & 2.86 & -1.25 & -0.30 \\
\hline & $(15.733 .3)$ & $(1.87)$ & $(17.43)$ & $(13.8)$ & $(18.1)$ & $(3.5)$ & $(70.9)$ & $(32.9)$ & (10.4) \\
\hline \multirow{2}{*}{ AF-646 } & 3.98 & 2.92 & 3.91 & 0.08 & 0.04 & 0.02 & -1.29 & -1.65 & -0.17 \\
\hline & $(33.600 .0)$ & $(1.46)$ & $(30.50)$ & (13.6) & (14.9) & $(3.3)$ & $(63.2)$ & $(33.0)$ & (10.1) \\
\hline \multirow{2}{*}{ Rochedo } & -2.34 & -41.28 & -2.46 & -0.04 & 0.01 & 0.02 & -1.57 & 2.29 & 0.15 \\
\hline & $\$ 4.666 .7)$ & $(1.45)$ & (31.34) & $(13.5)$ & $(15.2)$ & $(3.2)$ & $(66.2)$ & $(40.1)$ & $(10.5)$ \\
\hline \multirow{2}{*}{ AF-1749 } & -4.61 & -65.56 & -5.24 & -0.08 & -0.42 & -0.13 & 0.36 & 2.27 & 0.07 \\
\hline & $(37.333 .3)$ & $(1.36)$ & (31.83) & $(13.2)$ & $(14.5)$ & (2.9) & $(70.1)$ & $(40.3)$ & (11.0) \\
\hline \multirow{2}{*}{ G. Mine } & -0.44 & 39.29 & 0.74 & 0.03 & 0.06 & 0.01 & 1.30 & 2.27 & 0.06 \\
\hline & $(39.200 .0)$ & (1.6) & $(40.06)$ & (13.7) & $(15.8)$ & (3.4) & $(71.0)$ & $(40.4)$ & (10.4) \\
\hline \multirow{2}{*}{ Hy Mark } & 9.62 & -77.00 & 6.40 & -0.22 & -0.75 & 0.01 & -1.67 & -1.91 & 0.19 \\
\hline & $(61.333 .3)$ & $(1.22)$ & $(46.73)$ & $(12.5)$ & $(13.5)$ & $(3.2)$ & $(61.7)$ & (29.9) & (11.8) \\
\hline $\mathrm{SD}\left(\mathrm{g}_{\mathrm{i}}\right)$ & 0.71 & 44.04 & 1.23 & 0.15 & 0.28 & 0.04 & 0.19 & 0.84 & 0.12 \\
\hline $\mathrm{SD}\left(\mathrm{g}_{\mathrm{i}}-\mathrm{g}_{\mathrm{j}}\right)$ & 1.09 & 68.22 & 1.91 & 0.24 & 0.43 & 0.06 & 0.29 & 1.30 & 0.18 \\
\hline
\end{tabular}

${ }^{1}$ See Table 1.

Regarding total number of fruits and yield, it was found that the effect of SCA of one parent when crossed with itself $(i=j)$ was positive for the parents Rochedo, AF1749, Gold Mine and Hy Mark. The SCA estimate for flesh firmness was negative for the parent Rochedo only. On the other hand, for soluble solids, the SCA estimate of parent Meloa was positive, versus negative estimates of the others. The SCA of the 15 hybrid combinations $(i \neq j)$, indicated the crosses Meloa x Rochedo, Meloa x AF-646 and AF-1749 $\mathrm{x}$ AF-646 as most promising for total number of fruits. For yield, the SCA values were highest for the and Honey Dew which together account for more than $80 \%$ of the melon exported from the port of Natal (Sales Júnior et al. 2006). Besides these, the cultivation of the melon types Cantaloupe, Charentais and Galia, has been expanded due to the rising price in foreign markets.

Considering the great diversity of melon, breeding programs should focus on more than one melon type. In this sense, the choice of the best population in a study also depends on the goal of the program. If the purpose is to produce Cantaloupe melons, one should obviously choose the best of crosses involving the parent Hy Mark. 
Table 3. Estimates of the specific combining ability (s) of 4 traits evaluated in 15 melon crosses

\begin{tabular}{|c|c|c|c|c|}
\hline \multirow{2}{*}{ Cross } & \multicolumn{4}{|c|}{$\mathbf{s}_{\mathrm{ij}}$} \\
\hline & TNF $^{1}$ & YD $\left(\mathrm{tha}^{-1}\right)$ & FF (N) & SS (\%) \\
\hline 1. Meloa & -5.46 & -6.58 & 0.90 & 0.17 \\
\hline 2. AF-646 & -7.99 & -8.01 & 1.76 & -0.45 \\
\hline 3. Rochedo & 5.74 & 5.56 & -0.73 & -0.63 \\
\hline 4. $\mathrm{AF}-1749$ & 12.94 & 11.62 & 1.21 & -0.23 \\
\hline 5. Gold Mine & 6.48 & 7.88 & 1.29 & -0.56 \\
\hline 6. Hy Mark & 8.48 & 3.26 & 4.99 & -0.45 \\
\hline $1 \times 2$ & 9.14 & 14.33 & -3.83 & -0.53 \\
\hline $1 \times 3$ & 13.88 & 13.51 & 1.33 & 0.03 \\
\hline $1 \times 4$ & -7.06 & -7.16 & 4.56 & -0.28 \\
\hline $1 \times 5$ & -10.69 & -12.43 & 0.99 & 0.13 \\
\hline $1 \times 6$ & 5.64 & 4.92 & -4.85 & 0.31 \\
\hline $2 \times 3$ & 3.41 & 1.97 & 2.53 & 1.16 \\
\hline $2 \times 4$ & 8.08 & 5.27 & 2.53 & -0.40 \\
\hline $2 \times 5$ & -2.22 & -3.25 & -0.42 & 0.54 \\
\hline $2 \times 6$ & -2.42 & -2.29 & -4.32 & 0.13 \\
\hline $3 \times 4$ & -12.26 & -11.21 & -7.41 & 0.67 \\
\hline $3 \times 5$ & 5.98 & 2.22 & 1.13 & -0.42 \\
\hline $3 \times 6$ & -22.49 & -17.62 & 3.89 & -0.17 \\
\hline $4 \times 5$ & -11.49 & -10.45 & -0.83 & 0.13 \\
\hline $4 \times 6$ & -3.16 & 0.32 & -1.26 & -0.12 \\
\hline $5 \times 6$ & 5.48 & 8.15 & -3.44 & 0.74 \\
\hline $\mathrm{SD}\left(\mathrm{S}_{\mathrm{ii}}\right)$ & 1.61 & 2.97 & 1.89 & 0.27 \\
\hline $\mathrm{SD}\left(\mathrm{S}_{\mathrm{ij}}\right)$ & 1.94 & 3.29 & 2.30 & 0.33 \\
\hline $\mathrm{SD}\left(\mathrm{S}_{\mathrm{ii}}-\mathrm{S}_{\mathrm{jj}}\right)$ & 2.19 & 3.82 & 2.60 & 0.37 \\
\hline $\operatorname{SD}\left(S_{i j}-S_{i k}\right)$ & 2.90 & 5.05 & 3.43 & 0.48 \\
\hline $\mathrm{SD}\left(\mathrm{S}_{\mathrm{ij}}-\mathrm{S}_{\mathrm{kl}}\right)$ & 2.70 & 4.68 & 3.18 & 0.45 \\
\hline
\end{tabular}

${ }^{1}$ See Table 1.

Likewise, if the goal is a Honey Dew, one should identify the best cross of among those involving parent AF-1749. If the goal is to produce a pele de sapo or Meloa, then the best hybrid combination involving the parent Meloa ought to be selected. For Amarelo melon there are more options, since three Amarelo parents were included in the diallel (AF-646, Rochedo and Gold Mine).

On the other hand, it is known that in melon improvement many traits are to be taken into consideration for selection. A good genotype must have a high yield, a market-standard size, good flesh thickness, small internal cavity, high flesh firmness and high soluble solids content (Nunes et al. 2005). It is therefore difficult to identify a cross that meets all these requirements.

According to Cruz and Vencovsky (1989), the breeder must choose a cross with high SCA and with at least one parent with a high GCA estimate. The idea is to join great variability and high frequency of favorable alleles, important properties of a good segregating population. These traits allow the selection of lines with good performance. In addition, the cross mean and the mean of each parent are important to choose the best hybrid combination.

For Cantaloupe melon the best combination would be Gold Mine x Hy Mark. The parent Gold Mine is highyielding, has a high flesh firmness and high soluble solids content (Table 2). The parent Hy Mark is also productive, has a high content of soluble solids and a small internal cavity. The cross between them resulted in desirable SCA for yield, internal cavity size and soluble solids (Table 4). However, the SCA for flesh firmness was negative. One aspect that mitigates this result is that the GCA of Gold Mine is high (Table 2). The favorable alleles from this parent may be fixed in the selection process of Cantaloupe lines.

In the case of Honey Dew melon, often called "Orange Flesh" by producers, the cross with the largest number of desirable phenotypes would be AF-646 x AF-1749. This combination is interesting in view of the positive SCA values for total fruit number, yield and flesh firmness (Table 3). One drawback that could weigh in the choice of this cross is the low GCA estimate of these parents (Table 2). However, it is noteworthy that the cross mean for this trait did not differ from the others (Table 4).

For the production of Piel de Sapo or Meloa hybrids, the most recommended cross would be Meloa x Rochedo since the SCA is high for total number of fruits and yield (Table 3), although the GCA estimates for total number of fruits and yield were negative (Table 2). However, it is noteworthy that the means of total number of fruits and yield of the parent Rochedo were high (Table 2).

To obtain Amarelo hybrids, the most promising cross is AF-646 x Rochedo, in view of the high average yield (Table 4) and high SCA for all traits with a non-additive effect (Table 3). In addition, AF-646 has positive GCA for fruit number and yield, while Rochedo has positive GCA values for flesh firmness and soluble solids (Table 2).

Therefore, it was concluded that the traits total number of fruit, yield, flesh firmness and soluble solids were controlled by additive and non-additive effects, while the traits mean fruit weight, longitudinal diameter, flesh thickness and internal cavity size were controlled by additive effects only, and that the most indicated crosses for improvement of Cantaloupe, Honey Dew, Pele de Sapo/ Meloa and Amarelo melon are, respectively: Gold Mine x Hy Mark, AF-646 x AF-1749, Meloa x Rochedo and AF-646 $\mathrm{x}$ Rochedo. 
AKA Barros et al.

Table 4. Means of nine traits evaluated in 15 melon crosses

\begin{tabular}{|c|c|c|c|c|c|c|c|c|c|}
\hline \multirow[b]{2}{*}{ Cross } & \multicolumn{9}{|c|}{ Mean } \\
\hline & $\mathbf{T N F}^{1}$ & $\begin{array}{c}\text { MFW } \\
\text { (kg) }\end{array}$ & $\begin{array}{c}\text { YD } \\
(\text { t.hat }\end{array}$ & $\begin{array}{c}\text { TD } \\
\text { (cm) }\end{array}$ & $\begin{array}{l}\text { LD } \\
(\mathrm{cm})\end{array}$ & $\begin{array}{l}\text { FTh } \\
\text { (cm) }\end{array}$ & $\begin{array}{l}\text { ICS } \\
(\%)\end{array}$ & $\begin{array}{l}\text { FF } \\
(\mathbf{N})\end{array}$ & $\begin{array}{l}\text { SS } \\
(\%)\end{array}$ \\
\hline $1 \times 2^{2}$ & $40.533 .3^{a}$ & $1.80^{\mathrm{a}}$ & $45.59^{\mathrm{a}}$ & $14.4^{\mathrm{a}}$ & $16.6^{\mathrm{a}}$ & $3.4^{\mathrm{a}}$ & $66.9^{b}$ & $27.8^{b}$ & $8.9^{b}$ \\
\hline $1 \times 3$ & $38.933 .3^{b}$ & $1.58^{\mathrm{b}}$ & $38.40^{\mathrm{a}}$ & $13.8^{\mathrm{a}}$ & $15.8^{\mathrm{a}}$ & $3.5^{\mathrm{a}}$ & $64.6^{b}$ & $32.7^{\mathrm{a}}$ & $10.7^{\mathrm{a}}$ \\
\hline $1 \times 4$ & $15.733 .3^{c}$ & $1.52^{b}$ & $14.95^{c}$ & $13.8^{\mathrm{a}}$ & $16.1^{\mathrm{a}}$ & $3.0^{\mathrm{a}}$ & $67.7^{b}$ & $40.1^{\mathrm{a}}$ & $10.3^{\mathrm{a}}$ \\
\hline $1 \times 5$ & $16.266 .7^{\mathrm{c}}$ & $1.54^{\mathrm{b}}$ & $15.66^{\mathrm{c}}$ & $13.1^{\mathrm{a}}$ & $15.4^{\mathrm{a}}$ & $3.0^{\mathrm{a}}$ & $75.2^{\mathrm{a}}$ & $36.6^{\mathrm{b}}$ & $10.7^{\mathrm{a}}$ \\
\hline $1 \times 6$ & $42.666 .7^{\mathrm{a}}$ & $1.45^{\mathrm{b}}$ & $38.66^{\mathrm{a}}$ & $13.4^{\mathrm{a}}$ & $15.5^{\mathrm{a}}$ & $3.4^{\mathrm{a}}$ & $63.6^{\mathrm{a}}$ & $28.7^{\mathrm{b}}$ & $11.1^{\mathrm{a}}$ \\
\hline $2 \times 3$ & $38.666 .7^{b}$ & $1.40^{\mathrm{b}}$ & $34.12^{b}$ & $13.5^{\mathrm{a}}$ & $16.9^{\mathrm{a}}$ & $3.4^{\mathrm{a}}$ & $57.6^{d}$ & $33.5^{\mathrm{b}}$ & $12.0^{\mathrm{a}}$ \\
\hline $2 \times 4$ & $41.066 .7^{\mathrm{a}}$ & $1.35^{\mathrm{b}}$ & $34.63^{b}$ & $13.1^{\mathrm{a}}$ & $15.1^{\mathrm{a}}$ & $3.1^{\mathrm{a}}$ & $65.3^{b}$ & $37.7^{\mathrm{b}}$ & $10.4^{\mathrm{a}}$ \\
\hline $2 \times 5$ & $34.933 .3^{b}$ & $1.48^{\mathrm{b}}$ & $32.09^{b}$ & $13.7^{\mathrm{a}}$ & $14.7^{\mathrm{a}}$ & $3.3^{\mathrm{a}}$ & $69.8^{\mathrm{b}}$ & $34.7^{\mathrm{b}}$ & $11.3^{\mathrm{a}}$ \\
\hline $2 \times 6$ & $44.800 .0^{\mathrm{a}}$ & $1.38^{\mathrm{b}}$ & $38.71^{\mathrm{a}}$ & $12.9^{\mathrm{a}}$ & $14.2^{\mathrm{a}}$ & $3.1^{\mathrm{a}}$ & $69.0^{\mathrm{b}}$ & $28.8^{\mathrm{c}}$ & $11.0^{\mathrm{a}}$ \\
\hline $3 \times 4$ & $14.400 .0^{\mathrm{c}}$ & $1.29^{\mathrm{c}}$ & $11.78^{\mathrm{c}}$ & $13.2^{\mathrm{a}}$ & $13.9^{\mathrm{a}}$ & $3.1^{\mathrm{a}}$ & $63.0^{\mathrm{b}}$ & $27.5^{\mathrm{c}}$ & $11.7^{\mathrm{a}}$ \\
\hline $3 \times 5$ & $36.800 .0^{b}$ & $1.35^{\mathrm{b}}$ & $31.20^{\mathrm{b}}$ & $12.8^{\mathrm{a}}$ & $15.4^{\mathrm{a}}$ & $3.3^{\mathrm{a}}$ & $68.7^{b}$ & $36.0^{\mathrm{b}}$ & $10.6^{\mathrm{a}}$ \\
\hline $3 \times 6$ & $18.400 .0^{\mathrm{c}}$ & $1.47^{\mathrm{b}}$ & $17.01^{\mathrm{c}}$ & $13.7^{\mathrm{a}}$ & $14.7^{\mathrm{a}}$ & $3.2^{\mathrm{a}}$ & $66.5^{b}$ & $36.8^{\mathrm{b}}$ & $11.0^{\mathrm{a}}$ \\
\hline $4 \times 5$ & $17.066 .7^{\mathrm{c}}$ & $1.459^{b}$ & $15.75^{\mathrm{c}}$ & $13.7^{\mathrm{a}}$ & $15.1^{\mathrm{a}}$ & $3.3^{\mathrm{a}}$ & $67.5^{b}$ & $38.3^{\mathrm{a}}$ & $11.1^{\mathrm{a}}$ \\
\hline $4 \times 6$ & $35.466 .7^{\mathrm{b}}$ & $1.44^{\mathrm{b}}$ & $32.16^{\mathrm{c}}$ & $13.6^{\mathrm{a}}$ & $14.4^{\mathrm{a}}$ & $3.2^{\mathrm{a}}$ & $64.4^{\mathrm{b}}$ & $35.8^{\mathrm{b}}$ & $11.0^{\mathrm{a}}$ \\
\hline $5 \times 6$ & $48.266 .7^{\mathrm{a}}$ & $1.52^{b}$ & $45.98^{\mathrm{a}}$ & $13.8^{a}$ & $15.7^{\mathrm{a}}$ & $3.4^{\mathrm{a}}$ & $64.9^{b}$ & $33.6^{\mathrm{b}}$ & $11.9^{\mathrm{a}}$ \\
\hline
\end{tabular}

${ }^{1}$ See Table 1

${ }^{2}$ Means followed by the same letter belong to the same group by the Scott-Knott test at $5 \%$ probability

\section{Análise dialélica da produção e de características de qualidade de frutos do meloeiro}

RESUMO - O objetivo do presente trabalho foi estimar as capacidades geral e especifica de combinação, com o intuito de identificar as melhores combinações hibridas de melão. Seis genitores e os seus respectivos hibridos foram avaliados em um experimento em blocos casualizados com três repetições. As características avaliadas foram número total de frutos, peso médio do fruto, produtividade, diâmetro transversal, diâmetro longitudinal, espessura da polpa, proporção da cavidade interna, firmeza da polpa e sólidos solúveis. As características número total de frutos, produtividade, firmeza de polpa e teor de sólidos solúveis são controladas por efeitos aditivos e não aditivos, enquanto que as características peso médio do fruto, diâmetro longitudinal, espessura da polpa e proporção da cavidade interna são controladas somente por efeitos aditivos. Os cruzamentos mais apropriados para o melhoramento de melão dos tipos cantaloupe, honey dew, pele de sapo/meloa e amarelo são respectivamente os seguintes: Gold Mine x Hy Mark, AF-646x AF-1749, Meloa x Rochedo e AF646 e Rochedo.

Palavras-chave: Cucumis melo, capacidade de combinação, escolha de genitores, seleção.

\section{REREFENCES}

Abadia J, Cuarteiro ML and Nuez F (1985) Herencia de caracteres cuantitativos en melón. Instituto Nacional de Investigación y Tecnología Agraria y Alimentaria 28: 83-91.

Bernardo R (2002) Breeding for quantitative traits in plants Stemma, Woodbury, 369p.

Carmo Filho F and Oliveira OF (1989) Mossoró: um município do semi-árido nordestino - características e aspectos florísticos. Coleção Mossoroense, Mossoró, 62p. (Série B, nr. 672).
Crisóstomo JR, Miranda FR, Medeiros JF and Freitas JG (2008) A cadeia produtiva do melão no Brasil. In Albuquerque ACS and Silva AG (org) Agricultura tropical: quatro décadas de inovações tecnológicas, institucionais e políticas. Embrapa Informação Tecnológica, Brasília, p. 579-594.

Cruz CD (2008) Programa Genes: Biometria. Editora UFV, Viçosa, 278p.

Cruz CD and Vencovsky R (1989) Comparação de alguns métodos de análise dialélica. Revista Brasileira de Genética 12: 425 438 . 
Cuarteiro MLGJ, Abadia J and Nuez F (1985) Herencia de caracteres cualitativos en melón. Instituto Nacional de Investigación y Tecnología Agraria y Alimentaria 28: 72-82.

Ferreira MAJ, Braz LT, Queiróz MA, Churata-Masca MGC and Vencovsky R (2002) Capacidade de combinação em sete populações de melancia. Pesquisa Agropecuária Brasileira 37: $963-970$.

Ferreira FM, Ribeiro Júnior JI, Pacheco CAP, Silva CHO and Martins Filho S (2004) Genetic components of combining ability in a complete diallel. Crop Breeding and Applied Biotechnology 4: 338-343.

Feyzian E, Dehghani H, Rezai AM and Javaran MJ (2009) Diallel cross analysis for maturity and yield-related traits in melon (Cucumis melo L.). Euphytica 168: 215-223.

Griffing BA (1956) concept of general and specific combining ability in relation to diallel crossing systems. Australian Journal Biology Science 9: 463-493.

Hallauer AR and Miranda Filho JB (1988) Quantitative genetics in maize breeding. Iowa, Ames, 468p.

Kalb TJ and Davis DW (1984a) Evaluations of combining ability, heterosis and genetic variance for fruit quality characteristics in bush muskmelon. Journal American Society Horticulture Science 109: 411-415.

Kalb TJ and Davis DW (1984b) Evaluations of combining ability, heterosis and genetic variance for fruit quality characteristics in bush muskmelon. Journal American Society Horticulture Science 109: 416-419.

Kitroongruang N, Poo-Swang W and Tokumasu S (1992) Evaluation of combining ability, heterosis and genetic variance for plant growth and fruit quality characteristics in Thainmelon (Cucumis melo L.). Science Horticulture 50: 79-87.

Lima LL, Nunes GHS and Bezerra Neto F (2004) Coeficientes de variação de algumas características do meloeiro: uma proposta de classificação. Horticultura Brasileira 22: 14-17.

Luan F, Sheng Y, Wang Y and Staub JE (2010) Performance of melon hybrids derived from parents of diverse geographic origins. Euphytica 173: 1-16.
Lippert FL and Legg PD (1972) Diallel analysis for yield and maturity characteristics in muskmelon cultivars. Journal American Society Horticulture Science 97: 87-90.

Monforte AJ, Oliver M, Gonzalo MJ, Alvarez JM and DolcetSanjuan R (2004) Identification of quantitative trait loci involved in fruit quality traits in melon (Cucumis melo L.) Theoretical and Applied Genetics 108: 750-758.

Nunes GHS, Santos Júnior JJS, Andrade FV, Bezerra Neto F, Almeida AHB and Medeiros DC (2004) Aspectos produtivos e de qualidade de híbridos de melão cultivados no agropólo MossoróAssu. Horticultura Brasileira 22: 744-747.

Nunes GHS, Santos Júnior JJ, Andrade FV, Bezerra Neto F, Menezes JB and Pereira EWL (2005) Desempenho de híbridos do grupo inodorus em Mossoró. Horticultura Brasileira 23: 90-94.

Paris MK, Zalapa JE, McCreight JD and Staub JE (2008) Genetic dissection of fruit quality components in melon (Cucumis melo L.) using a RIL population derived from exotic x elite US Western Shipping germplasm. Molecular Breeding 22: 405419.

Sales Júnior R, Dantas F, Salviano AM and Nunes GHS (2006) Qualidade do melão exportado pelo porto de Natal-RN. Ciência Rural 36: 286-289.

Singh MJ and Randhawa KS (1990) Evaluation of heterosis and ability for traits in muskmelon. Indian Journal Horticulture 47: 228-232.

Valério IP, Carvalho FIF, Oliveira AC, Souza VQ, Benin G, Schmidt DAM, Ribeiro G, Nornberg R and Luch H (2009) Combining ability of wheat genotypes in two models of diallel analyses. Crop Breeding and Applied Biotechnology 9: 100-107.

Vianna JMS (2000) The parametric retrictions of the Griffing diallel analysis model: combining ability analysis. Genetic and Molecular Biology 23: 877-881.

Zalapa JE, Staub JE and McCreight JD (2006) Generation means analysis of plant architectural traits and fruit yield in melon. Plant Breeding 125: 482-487. 